\title{
Backpacking's future and its drifter past
}

\author{
Michael O’ Regan
}

\begin{abstract}
Purpose - The purpose of this paper is to deconstruct the backpacker label by reconstructing it using the historical antecedent of drifting. Following the deconstruction of backpacking's near past, the author build a clearer conceptual foundation for backpacking's future.

Design/methodology/approach - The study is framed by scenario planning, which demands a critical review of the backpacking and an appreciation of its history in order to understand its future.

Findings - Backpacking, ever evolving, remains difficult to articulate and challenges researchers to "keep up" with its complexity and heterogeneity. This paper argues that researchers must learn more about how backpacking "works" by opening a dialogue with its past, before engaging in further research. The paper finds that a poor conceptualisation of backpacking has led to a codification of backpacker criteria.

Practical implications - Backpacking remains a research topic which draws disparate researchers using criteria that produces disparate results and deviations. By understanding its past, researchers will be better placed to explore the emancipatory impulses that drive backpackers today and in the future.

Originality/value - This papers' value lies in the retrospection process which explores backpacking's near past so as to "make sense" of present research and present scenarios for it is the immediate future. The paper re-anchors backpacking by investigating the major historical, social and cultural events leading up to its emergence.
\end{abstract}

Keywords Scenario planning, Backpackers, Backpacking, Drifting, Tourism futures, Tourism history

Paper type Research paper

\section{Introduction}

Backpacking as an "alternative" form/type of tourism generates a distinct way of "being-in-the-world" as individuals characterised by extensive spatial mobility and time and space flexibility travel for up to one year or more on routes that span the globe (Berdychevsky et al. , 2013). There has been a rapid increase in their visibility as a distinct form of tourism. From books to movies, the media is now flush with "backpacking" related images, films, fiction, oral histories, documentaries, reality television shows and soap operas (O'Regan, 2016). However, as a label or category, "backpacker" and "backpacking" can generate a surprising amount of debate. From the scholars who contest the conflicting claims to its origin (Loker-Murphy and Pearce, 1995), the entrepreneurs who seek to extend it as a label (Bell, 2008), to the backpackers who wish to distance themselves from it (O'Regan, 2016); there is little agreement as to the nature of backpacking homogeneity or heterogeneity, its past or its future. This paper argues that backpacker research in the social sciences has stalled as form-related attributes have become fixed defining criteria for manipulative hypotheses stated in advance in propositional form and subjected to flawed empirical tests.

The purpose of this paper is to deconstruct the backpacker label through a past-to-future scenario planning perspective. This approach includes exploring current "backpacker" research through a critical lens, deconstructing backpacking's "drifter past", and rebuilding a new conceptual foundation for the future. As thinking about future scenarios requires an accurate appreciation of history in order to understand the future (Yeoman, 2008), this paper explores drifting, which has symbolic, cultural, structural and historic continuity with backpacking, and is seen as the most direct precursor of backpacking (Hannam and Diekmann, 2010; Sørensen, 2003).
Michael O' Regan is based at the Bournemouth University, Dorset, UK.

Received 30 April 2018 Revised 4 September 2018 Accepted 5 September 2018

(C) Michael O' Regan. Published in Journal of Tourism Futures. Published by Emerald Publishing Limited. This article is published under the Creative Commons Attribution (CC BY 4.0) licence. Anyone may reproduce, distribute, translate and create derivative works of this article (for both commercial and non-commercial purposes), subject to full attribution to the original publication and authors. The full terms of this licence may be seen at http://creativecommons.org/ licences/by/4.0/legalcode 


\section{Backpacker research: disparities and incongruities}

There is some contestation as to where the backpacker label originated (Slaughter, 2004). While first noted at an academic conference by Pearce (1990), it was already a internal-external dialectic of identification (Jenkins, 1996) in the early 1980s, with Smith (1992) noting its use by Boracayans in the Philippines in 1985. Whatever its origins, the external identification of "backpacker" became an internal identification used by those who shared an identity based on their form of travel as well as a marketing concept used by business. After Pearce (1990) utilised a quiz/questionnaire inserted in the free Aussie Backpacker magazine during 1989 (596 questionnaires), he found backpackers to be predominantly young, on an extended holiday, with a preference for budget accommodation. He found they had a flexible and informal travel itinerary and placed an emphasis on meeting people and participating in a range of activities. Loker-Murphy and Pearce (1995) built on this, by administering a questionnaire and drawing on data from the annual visitor survey conducted at Australia's major international airports. They extracted data from those aged between 15 and 29 years of age, with holiday as main purpose of trip, a duration of stay of four weeks or more to confirm the 1990 criteria. The findings met the demand by authorities and businesses in Australia for an internationally accepted, comprehensive definition (Wallace, 1991). Subsequent research based on the criteria produced by Loker-Murphy and Pearce (1995) and others confirmed backpackers extended travel, a tendency towards low spending and interaction with other travellers (Hecht and Martin, 2006; Murphy, 2001; Riley, 1988).

Whilst other labels have been applied to these travellers included "youth travelers" (Adler, 1985), "free independent travellers" (Clarke, 2004), "long-term budget travelers" (Riley, 1988), "noninstitutionalised tourists" (Uriely et al., 2002), "non-tourists" (Tucker, 2003), "budget tourist/ economy tourists" (Elsrud, 2001) and "anti-tourists" (Maoz, 2007), the "backpacker" label has become dominant (Elsrud, 2001; Hampton, 1998; Pearce, 1990; Scheyvens, 2002; Smith, 1992; Uriely et al., 2002). This has made the category legible for researchers, its use instrumental in researching the demographic and social background of backpackers. They were cast as a distinct "category" of tourism that is seen as categorically different from mass tourism or "institutionalized" tourism flows (Sørensen, 2003). Backpackers continue to attract attention in sociological, anthropological and psychological research, based on the priori-assumption that not researching difference is "dangerous", "since it will surely result in at least some of these visitors being dissatisfied or not particularly well catered for" (Loker-Murphy, 1997, p. 25). While a shift from unifying depictions of the backpacker as a general type "toward an approach that stresses its diverse and plural characteristics" (Uriely, 2005, p. 205) is welcome, research have primarily utilized the criteria developed by Pearce (1990) to analyse backpacker homogeneity/ heterogeneity in terms of nationality, motivation and gender (Hampton, 1998; Elsrud, 2001; Maoz, 2007; Murphy, 2001; Noy, 2004).

Codification of criteria is used to know the "proper" location, ages and characteristics of backpackers and "proper" backpacker practices. Utilising form related criteria, such as age, luggage type, accommodation usage, etc., backpackers are placed in a controlled context so as to observe, measure and quantify them. For example, researchers now indicate the minimum length of travel time backpackers must be "on the road for", with researchers often drawing samples from those staying in hostels (Hecht and Martin, 2006; Hughes et al., 2009; Pearce and Foster, 2007; Thyne et al., 2004). Larsen et al. (2011) used a hostel stay as a criterion to identify backpackers as other researchers identify a backpacker as spending at least one night in a hostel or backpacker accommodation. Other studies link their research to usage of particular internet groups and sites online (Luo et al., 2015; Paris, 2012) and even their use of a backpack (Chen et al., 2014; Pearce and Foster, 2007). Research risks missing the evolving nature of backpacking as researchers search for niches, taxonomies, segments or typologies.

Codification of criteria does have benefits. Backpacker research originates across different disciplines such as medicine, management and business studies, economics and sociology. The global scale of backpacking research demands exchange of knowledge between geographically dispersed researchers. Codification allowed the backpacker phenomenon and the backpacker label to become a worldwide term of description and made it possible to talk of a developing transnational socio-spatial sub-lifestyle. However, codification has also produced contradictory 
classifications, typologies, clusters, taxonomies and segments as deviations from criteria are not unusual. There has been a recent trend to focus on deviations from the "standardized" backpacker characteristics, with researchers finding cohorts of "humanistic backpackers" (Uriely et al., 2002), "holiday hippies" (Westerhausen, 2002), "conformist backpackers" (Hottola, 2008), "flashpackers" (Paris, 2012), the "Backpacker Plus" (Cochrane, 2005), "backpacker tourists" (Bell, 2005), "youth train backpackers" (Bae and Chick, 2016) and "study backpackers" (Jarvis and Peel, 2005). Those revealed as deviating from these criteria are exposed either as a new type of backpacker with specific type-related attributes or deviants/non backpackers like "begpackers" (Saidi, 2018), whom Cohen (1972, 1973) should have approved!

Backpacking research has been largely disconnected from its near past as backpacking is perceived to have become institutionalized and retrenched through a combination of touristic, educational and economic discourses (Cohen, 2003). The backpacker label has become so unrooted that it has become redundant for increasing numbers of researchers who label all "budget travellers" (Larsen et al., 2011) as backpackers, "gap year" travellers as backpackers (O'Reilly, 2006), "youth students" (Richards, 2015) as backpackers and those on working visas as backpackers (Allon, 2004). There has also been a trend in applying macro-level concepts and trends to backpackers such as sustainability, service quality, authenticity and loyalty (Brochado et al., 2015; laquinto, 2015). Finally, as backpacking has progressively widened its sociocultural base by drawing adherents from Asia, Africa and South America, researchers have disregarded the particular historical backgrounds in which drifting and backpacking emerged in the west, and have applied western concepts of backpacking to other nationalities such as Chinese backpackers (Chen et al., 2014).

Pearce (1990), however, had recognised that the emergence of backpacking was partially because of the "marginal" behaviour of the "hippie/drifter" type during the 1960s and 1970s, with Eric Cohen's (1972, 1973) conceptualization of "drifters" the conceptual basis for early backpacker research. Cohen (2004, p. 44) himself noted that "If the model for the drifter was the tramp, the drifter is the model for the backpacker". However, many scholars argue that backpacker identifies are too far (re)constructed by the (social) media and the tourism industry to be linked with drifting (Molz and Paris, 2015). They argue that any unconventional elements have stripped away, with resold backpacking as a touristic pursuit. The shift from the "drifter" to the "backpacker" label has come to be seen as a disjuncture (Elsrud, 2001; Sørensen, 2003), creating a break with backpackers past and future. This paper applies scenario planning to reconceptualise backpacking's past, so as to reconceptualise backpacking to account for backpacking today and in the future.

\section{Methodology}

The disparities, incongruities and deviations in backpacker research demand a retrospective look at backpacking's near past. Scenario planning has been used by businesses, academics and government agencies for strategic futures planning since the 1950s (Bradfield et al., 2005). Given the subjective, personalised and heuristic nature of scenario planning, it is thought to leave "many academics uncomfortable" (Schoemaker, 2004). This discomfort may deter academics from subjecting a topic to scholarly scrutiny. However, scenario planning can be useful to academics, since the process may act as a cognitive aid to overcome limitations and framing biases (Page et al., 2010; Yeoman, 2008). It may lead academics to update their judgment, and induce changes in their thinking. More than simply predicting future backpacking scenarios, the paper challenges current assumptions about backpacking and casts a critical eye on backpacker research.

\section{The drifters}

There have been multiple discursive associations linking backpacking to earlier forms and types of travel like the "Grand Tour" (O’Reilly, 2005; Riley, 1988; Shaffer, 2004), German Youth Movements such as the Wandervogel (Desforges, 1998); "Tramping" (Adler, 1985), organisations like the Young Men's Christian Association (Ryan and Mohsin, 2001) and the Youth Hostel movement 
(Loker-Murphy and Pearce, 1995). While these frequently used antecedents offer a quick analysis, their relationships are ill defined or charted. Indeed, backpacking could just as easily be associated with medieval European pilgrims, colonial explorers, the peripatetic's, flaneur explores or missionaries. Löfgren $(2002$, p. 7) cautions against the sort of catch-all narrative that "fall[s] into evolutionary or devolutionary traps, like 'from the Grand Tour to Europe on $\$ 5$ a day' ". While Erik Cohen $(1971$, p. 224) noted the "pennyless, wandering around without a clear aim or a definite itinerary, looking for a good time, a meal, a place to sleep, or an adventure", Cohen's (1972) typology of tourist roles based on novelty and familiarity identified the drifter on a continuum within tourism studies (Cohen, 2007). Cohen argues that while earlier youth movements were romantic and intended to serve a "constructive" social purpose; the "drifter" was "individualistic and least institutionalised" (Cohen, 1973, p. 89) and "wandered furthest from the beaten track" (Cohen, 1973, p. 89). He argues that drifter's made their first appearance after the Second World War when students and other middle class youths started to hitch-hike their way through Europe. The drifter strived more than the ordinary tourist to reach places and people that are "really" authentic; and "would display considerable touristic angst that places or events that appear authentic are in fact staged" (Cohen, 2004, p. 46). Cohen's (1972, p. 168) idealised drifter tended to:

[...] make it wholly on his own, living with the people and often taking odd-jobs to keep himself going. He tries to live the way the people he visits live [...] The drifter has no fixed itinerary timetable and no well-defined goals of travel. He is almost wholly immersed in his host culture.

The drifter was described as the complete opposite of the mass tourist (Cohen, 1972). The drifter is "individualistic", "disdainful of ideologies", "un-patriotic", "hedonistic" and "anarchistic" (Cohen, 1973) and shunned "any kind of connection with the tourist establishment, and considers the ordinary tourist experience phony" (Cohen, 1972, p.168). Cohen acknowledges the drifter as a "child of affluence, who reacts against it. He is young, often a student or a graduate, who has not yet started to work" (Cohen, 1972, p. 175) and "usually settles down to an orderly middle-class career" (Cohen, 1972, p. 176). Cohen's (1973) idealised drifter has no fixed itinerary or timetable and no well-defined goals of travel and seeks "to see the world as it really is" (p. 95) through "begging, scavenging and 'sharing' food and lodgings with friends and acquaintances" (Cohen, 1973, p. 95). He notes how their involvement in the host community sets them apart with time spent in one place an important determinant of social involvement.

Cohen's (1973) paper also described the emergence of what he describes as a subculture of drifters who travelled and congregated in "drifter communities". He argues that these drifter tourists were a different kind of social category. They were not as ideological, but individualistic, and as drifter itineraries formed, "fixed travelling patterns, established routines and a system of tourist facilities and services catering specifically to the youthful mass-tourist" (Cohen, 1973, p. 95) came into existence. Drifting became encumbered by all the "paraphernalia of mass tourism" (Cohen, 1973, p. 95) against which his idealised drifters rebelled. These drifter tourists were not as motivated to seek to mix with host populations, customs and landscape. While the idealised drifter did not die, Cohen recast the category into a typology based on work by Keniston's (1968) about countercultural drug users, and work by the sociologist Yablonsky (1968). Cohen utilised the dimensions of involvement and time to create a four-fold typology of drifters. His "Adventurers" corresponded to the idealised drifter as they were, outward oriented and full time. The inward oriented "Itinerant Hippie", drifted aimlessly from one "hippie" community to another in search for drug culture and was oblivious to the native environment. The part time outward oriented "mass-drifter" was linked to college youth, with limited time and stuck to the "drifter-tourist establishment" (Cohen, 1973, p. 98). He argued they were "almost the complete opposite of its original prototype" (Cohen, 1973, p. 103). Finally, the part time, inward oriented "Fellow Traveller" merely associated with the "hippies". Cohen (1979) later provided a typology of modes of tourist experiences by situating drifting within what he called the experimental mode. He suggested those who travelled on his mode were pre-disposed to try out alternative ways of life as part of a quest for meaning. By 1982, Cohen argued that only a few fulltime drifters remained, and in a 2003 paper, he noted few backpackers had the competence, resourcefulness, endurance, fortitude, or ability to replicate his idealised drifter. Rather than the drifter tourist, he argues it was the "original; idealised drifter" which was the "ideal" (Cohen, 2003) to which backpackers are attracted, but cannot succeed. He argues backpacking has been stripped of its countercultural leanings, and comparable to conventional mass tourism. 


\section{A retrospective analysis of drifters}

A retrospective analysis identifies issues with the concept of the idealised drifter. While Cohen (1973) noted he conceived of the drifter in 1968, it was not until the early 1970's that he became interested in the phenomena of unconventional travellers. An anthropologist by training, his interest in tourism was marginal, and the intrusion of these travellers into his anthropological studies antagonised him (Cohen, 2007). The label drifter had been around for some time, with the novel Drifters by James A. Michener (1971), e.g., following six young characters from diverse backgrounds as they travelled together through parts of Spain, Portugal, Morocco and Mozambique. Cohen's $(2003,2007)$ conceptualisation of the "drifter" was influenced by one personal encounter in 1969 whilst carrying out anthropological fieldwork on poverty in Ayacucho, in the central Andes of Peru and linked this encounter to an anthropological study of Arab boys and tourists girl in Acre, Israel in 1966 (Cohen, 1971). However, Cohen's work lacked fieldwork, given he did not perceive himself as a tourism researcher (Cohen, 2007). There are contradiction is his work, as he describes the emergence of the drifter tourist as both sudden and gradual (Cohen, 1973). While he notes drifter tourists follow into areas which "individual drifters already started to penetrate in the earlier period" (Cohen, 1973, p. 92), it is difficult to establish timelines and whether drifters and drifter tourists interacted. This may be because Cohen never travelled with drifters, did fieldwork, or immerse himself in drifting. Given the lack of literature to substantiate the drifter conceptualization, his work obscures whether the idealised drifter existed or how drifter tourism emerged. Without forming a complete picture of drifting ensures our understanding of the emergence of backpacking remains fuzzy. There is little evidence for his idealised drifters, although there is evidence of new forms of travel in that period (Alderson, 1971). There is little evidence to suggest links between drifters and drifter tourists. This paper, therefore, re-align's backpacking to drifter tourism and the counterculture from which they emerged, rather than Cohen's idealised drifter. Cohen $(1972,1973)$ did link the drifter tourist to the counterculture, and mentioned links to the drug culture, the Vietnam War, economic affluence and broader alienative forces. He described the "loosening of ties and obligations, the abandonment of accepted standards and conventional ways of life, the voluntary abnegation of the comforts of modern technological society, and the search for sensual and emotional experiences [...] [that motivates them] to travel and live among different and more 'primitive' surroundings" (Cohen, 1973, p. 93).

Drifting emerged out of a disjuncture and a period of societal flux we call the counterculture.

There is considerable debate as to when the counterculture began as a cultural construct with most commentators placing it between 1960 and 1970. Marwick (1999) places it between 1958 and 1974. Roszak (1969) places the "1960s" within a broader setting that stretches from 1942 with the Beats, who sought mobility and experiences to escape from the predictability of suburban life. Emerging out of the "hipsters" who formed around black jazz and swing performers, a Bohemian counterculture began to evolve around North Beach in San Francisco in the early 1950s. As rental prices rose in the late 1950s and early 1960s, remnants moved to Haight-Ashbury, a neighbourhood in San Francisco near Golden Gate Park. This new "scene" (Irwin, 1977) attracted the white, middle class and the college educated, who were reacting to a loss of an overriding societal purpose. Fuelled by increased leisure time, societal affluence and the rapid postwar participation in the university system, these now relabelled "Hippies" sought escape - both literally and metaphorically (Miles, 2008). Previous temporal rhythms governing study, graduation and employment were shattering, suspended and replaced by a developing "socio-political-cultural concept" (Stephens, 1998) known as the counterculture. It was a "literal" escape from the consumerist suburban lifestyle, while metaphorically it was an escape from America (Miles, 2008). The district, which had an estimated 800 hippies in residence in 1965, had 15,000 by 1966 and 100,000 by the summer of 1967 (Falk and Falk, 2005). By the mid-1960s, the countercultural imagination was driven by the idea of "flowering" cities and creating alternative structures and enclaves where networked individuals and groups of similarly thinking people could coalesce. By the end of the 1960s, the "intense, spontaneous internationalism" (Neville, 1970, p. 14) saw enclaves across America and Europe develop (Lewis, 1972; Mills, 1973; Neville, 1970).

For a short period, this world was successful as individuals sought to set up their own economic, cultural and even political structures (alternative bookstores, pirate radio stations, food and clothing co-ops, underground magazines, health food stores and medical centres). The outlines 
of a world that individuals could relate to, aspire to and even inhabit emerged, which facilitated a "gut solidarity; sharing common aspirations, inspirations, strategy, style, mood and vocabulary" (Neville, 1970, p. 14). By 1967, the "the first flush of hippiedom was on the wane" (Neville, 1970, p. 31) as "hippie" enclaves were overflowing with tourists, reporters, underage runaways, undercover police, hard drugs, musicians, poets, dropouts, junkies, profiteers, hustlers, students and violent criminals (Didion, 1968/1995; Lewis, 1972). Attempts to create a community collapsed with problems of drug abuse, poverty, murder, prostitution, criminality and homelessness (Pendergast and Pendergast, 2000). Mills (1973) argues that western societies at that time would not provide material systems or organise spaces for the hippies but instead sought to control, regulate and eliminate them. The countercultural leaders "walked away" from politics and the enclaves to "live free" (Miles, 2008; Neville, 1970; Turner, 2006). Their refusal to conform, be subordinated or be appropriated meant geographical movement became generative of meaning. The "Haight is love" (Neville, 1970) spirit, energy and values fanned out through concerts, vehicles, communes, fashion, zines, literature and visual arts such as album covers. It led to "self-reliance, a means to discover one's singularity, a commitment to mobility, choice and change" (Leary, 1983, p. 253) rather than a life of stability. Roszak (1969, p. 240) argues the primary project of the countercultural imagination was to:

[...] proclaim a new heaven and a new earth so vast, so marvelous that the inordinate claims of technical expertise must of necessity withdraw in the presence of such splendor to a subordinate and marginal status in the lives of men. To create and broadcast such a consciousness of life entails nothing less than the willingness to open ourselves to the visionary imagination on its own demanding terms.

Cohen over emphasised alienation as the main motivating factor for drifter tourists, and under emphasised the importance of self-reliance, personal development and self-expression to individuals of the time. Detachment from the social structure was meant to be a graceful, temporary, selective and active attempt to create/find social structures that could carry and sustain their shared understandings and individual visions. Cohen under emphasised the counterculture outside the United in the UK, France and Australia, and the role of niche and mass media (like the music and style press). The media along with commercial interests from record companies to transport companies (Mills, 1973) drew in India, Nepal, Morocco, etc., into the countercultural orbit (Roszak, 1969). These countries symbolized freedom and independence (Cavallo, 2001) and escape from restrictions, laws and obligations and the beginning of "something wilder and weirder on out on the road" (Wolfe, 1968, p. 103). A new constructed (countercultural) imaginative map of the world gave "prominence to countries perceived to be spiritual and marginalized" (Stephens, 1998, p. 52); with "new possibilities derived from drugs, sexual freedom and a vague spirituality".

These drifter tourists were not as homogeneous as Cohen suggests, with the retrospective review indicating it would be more accurate to suggest that the drifter tourists were made up of various non-conformists, antiwar militants, counter-culturists, radicals, heads, "wanderers" (Vogt, 1976), "travelers" (Teas, 1974), dropouts, freaks, hippies and beatniks who had tapped into a countercultural mobility fantasy and a shared imaginary (Tomory, 1996). Adler (1989) notes how a single code need not be fully shared by those whose efforts yield a recognisable style of performance. Cohen over emphasises the role of idealised drifter, as it was the drifter tourist ideas and infrastructure (bars, restaurants, hotels, shops, sites) which were projected onto maps, novels, movies, images and guidebooks, and became embedded in western social imaginaries, which people would aspire to. Cohen also failed to describe why drifting reproduced itself, why it declined or explain why drifters rejoined the system (social structure) (Turner, 2006). Deflation in the late 1970s, a resurgence of neo-conservatism in many western countries, cold war conflicts, military dictatorships and proxy "hot" zones in many regions, combined to make the drift less popular. In addition, countries who had once welcomed the drifters now labelled their mobility "criminal", "deviant" or "alternative", with a number of countries refusing them entry visas and deporting them. This was further exasperated by the decline in value of western currencies and severe recession and stagflation between 1973 and 1983. However, there is no evidence to suggest drifting died (Hail, 1979) and backpacking did not simply appear in 1990 when introduced to an academic audience.

The death of the drifter label was linked to a tourism industry happy to de-link a new wave of travellers in the 1990s with anarchistic drifting, with some researchers loath to connect the 
reemergence of budget travel to "drifting" given the perceived end of the countercultural era (Cohen, 1982; Smith, 1992) and "hippie travellers" (Riley, 1988, p. 316). However, this type/form of travel had now been embedded in western social imaginaries as an organised field, with its building blocks, key story lines, narratives, cultural representations, affinities, performative conventions, understandings, regularities, ethos and practices in the public domain. This world retained its fluid and irregular shape and retained the core principles of its drifter tourist predecessors, by way of schemas of interpretation rather than explicit ideologies. Reignited desires in the late 1980s meant this world could again emerge, primarily in Australia, Thailand and the Philippines (Cohen, 1982; Riley, 1988; Smith, 1992).

Just as the drifting was enabled by low unemployment between 1946 and 1973, the mid-1980s saw the global economy improve once more. Combined with the fall of communism and the cold war; a period of affluence swept the western world. The countercultural imagination, from the beatniks to drifters and backpackers, has long been associated with "mobility fantasies", and drew dispersed individuals with different backgrounds and expectations that saw movement as a vehicle to explore new subjective experiences. Lonely Planet publications, always on the brink of bankruptcy found financial stability again as their guidebook sales took off in the 1980s (Wheeler and Wheeler, 2007).

Despite technology taking over, guidebooks were not evidence of backpacking, but the necessity of proximity and face-to-face contact. It indicates that "[u]topian desire doesn't go away [...]. in fact never really went away" (McKay, 1996, p. 6). It offered individuals an opportunity to travel as a form of "escape" (Pearce, 1990), with Cohen noting the drifter tourist "often goes abroad in order to get away from his homeland" (Cohen, 1973, p. 93). Iso-Ahola (1982) argues that people escape from such things as the dullness, stresses and monotony of everyday life, jobs, career decisions and/or relationship responsibilities (Riley, 1988) and are motivated by ideals of freedom, independence and adventure (Cohen, 2003).

\section{Future of backpacking}

People continue to be caught at the intersections of social pressures, education, career and family such as breaks between school and university, deaths in the family, divorces, marriage break-ups, career breaks/changes, workplace arrangements, retirement, health scares, redundancy, sabbaticals or post-military service. People will seek to escape oppressive, patriarchal and heteronormative structures, and "get distance" from former lives and identities (student, son, employee, husband, wife). Like the drifter tourists, some are transformed, self-induced mobility becoming a "substantial content of the reflexively organised trajectory of the self" (Giddens, 1991, p. 85), while others may merely buy into a temporary commodification of difference and otherness that is neither permanent nor long lasting. Many lack the time and inability to withdraw from economic necessity, or lack unrestrained freedom of travel, because of passport and visa restrictions imposed upon them. While some backpackers separate comfortably from the social structure, others are forced from it. Backpacking remains characterised by "audience-segregation" (Goffman, 1961), so that family, friends and employers do not figure, at least physically, during travel. Drifters and backpackers were never the free-floating individuals idealised by Cohen, with all those who travel tied into a network of regulations, conditions, provisos and obligations, tied up "with caring, guilt, responsibility and negotiation" (Larsen et al., 2006, p. 261).

This paper finds that backpacking's future can be found in its drifter past, but not the one idealised by Cohen or in codified criteria. Drifter tourism is backpackers past, but also its future as the countercultural imagination and the motivation to escape continues to drive contemporary backpacking. As individuals act on the basis of a shared imaginary that is culturally shared and socially transmitted, by those who purposefully enter this world, backpacking will continue. It is they who will inevitably modify and change backpacking over time as people, structure and contexts change. This is despite a market and managerial focus driven by lifestyle entrepreneurs, governments, consultants and academics that flatten backpacking's meaning and depth, strip it of its original countercultural symbols, and rewrite it within educational and touristic discourses. While it makes backpacking legible in a modern society, which is a prerequisite for governance 
and governance systems, it also seeks to blunt any meaning beyond that of mainstream disposable play (Cohen, 2018). While Cohen failed to address how interaction amongst drifters who shared the same cultural representation continually reproduced drifter tourism, backpacking's encounters of conflict and collaboration between inexperienced and experienced (recognised by those who enter backpacking as competent, credible and relevant) backpackers continually reproduce, rejuvenate and even transform backpacking through new myths, gossip, stories, routes and understandings. It is a formation that must continually shapeshift and transform to avoid co-option.

As long as backpackers are codified as objects of knowledge and separated from their near past, a business and managerial focus will dominate research. It is the failure of the scholastic imagination to adapt to a world on the move. Research needs to explore new overlapping imaginaries such as ecovillages, intentional communities, new age travellers (Kuhling, 2007), the Rainbow Family (González and Dans, 2018), Woofing (Ince, 2016), nomad houses, transformational festivals (St John, 2001; Saldanha, 2002), hospitality exchange (Ince and Bryant, 2018) and hitchhiking, but also mechanisms of exclusion and inequalities of mobility for different groups (females, disabled, LGBT, locals, older travellers) within these worlds. There is little understanding of backpackers beyond the western context and how other backpackers learn and interact. The future of backpacking is assured until those active in backpacking's past, present and future share a new imaginary that transitions towards new ways of escape. Some who engage in the above practices argue that climate change, pollution, the birth of artificial intelligence will possibly lead to societal upheaval and instability (Mannermaa, 1991) and a new social imaginary that is transnational in nature. The Rainbow Family prophecy, e.g., tells of a new tribe of "Rainbow Warriors", with values of wisdom, unity, harmony and love emerging after a revolutionary transition caused by environmental destruction (Niman, 1997).

\section{Conclusion}

The paper traces the development from "drifters" to backpackers, by reconnecting them retrospectively. This paper finds that backpackers inhabit a world endowed with history, desires, representations, understandings and intentions from its near past, to create a distinct type and form of tourism, with a memory of its own that has been represented, transmitted and recycled for nearly 60 years. Using scenario planning, this paper found an inherent power in the countercultural imagination, with continues to shape backpacking today, and also its future.

\section{References}

Adler, J. (1985), "Youth on the road: reflections on the history of tramping", Annals of Tourism Research, Vol. 12 No. 3, pp. 335-54.

Adler, J. (1989), "Travel as performed art", American Journal of Sociology, Vol. 94 No. 6, pp. 1366-91.

Alderson, F. (1971), The New "Grand Tour": Travelling Today through Europe, Asia Minor, India and Nepal, David \& Charles, Newton Abbot.

Allon, F. (2004), "Backpacker heaven: the consumption and construction of tourist spaces and landscapes in Sydney”, Space and Culture, Vol. 7 No. 1, pp. 49-63.

Bae, S.Y. and Chick, G. (2016), "A rail pass as a culture code among youth travelers: the case of Rail-Ro in Korea", Journal of Tourism and Cultural Change, Vol. 14 No. 1, pp. 27-44.

Bell, C. (2005), "The nervous gaze: backpackers in Africa", in Romero, M. and Margolis, E. (Eds), The Blackwell Companion to Social Inequalities, Blackwells, London, pp. 424-40.

Bell, C. (2008), "100\% Pure New Zealand: branding for back-packers”, Journal of Vacation Marketing, Vol. 14 No. 4, pp. 345-55.

Berdychevsky, L., Poria, Y. and Uriely, N. (2013), "Sexual behavior in women's tourist experiences: motivations, behaviors and meanings", Tourism Management, Vol. 35 No. 2, pp. 144-55.

Bradfield, R.M., Wright, G., Burt, G., Cairns, G. and van der Heijden, K. (2005), "The origins and evolution of scenario techniques in long range planning”, Futures, Vol. 37 No. 8, pp. 795-812. 
Brochado, A., Rita, P. and Gameiro, C. (2015), "Exploring backpackers' perceptions of the hostel service quality", International Journal of Contemporary Hospitality Management, Vol. 27 No. 8, pp. 1839-55.

Cavallo, D. (2001), A Fiction of the Past: The Sixties in American History, 2nd ed., St Martin's Press, New York, NY

Chen, G., Bao, J. and Huang, S. (2014), "Segmenting Chinese backpackers by travel motivations", International Journal of Tourism Research, Vol. 16 No. 4, pp. 355-67.

Clarke, N. (2004), "Free independent travellers? British working holiday makers in Australia", Transactions of the Institute of British Geographers, Vol. 29 No. 4, pp. 499-509.

Cochrane, J. (2005), "The backpacker plus: overlooked and underrated", paper presented at Atlas SIG Meeting - Backpacker Research Group Conference, The global nomad - an expert meeting on backpacker tourism, Advancing research agendas in backpacker travel, September, Bangkok.

Cohen, C. (1971), "Arab boys and tourist girls in a mixed jewish-arab community", International Journal of Comparative Sociology, Vol. 12 No. 4, pp. 217-33.

Cohen, E. (1972), "Towards a sociology of international tourism”, Social Research, Vol. 39 No. 1, pp. 164-82.

Cohen, E. (1973), "Nomads from affluence: notes on the phenomenon of drifter-tourism", International Journal of Comparative Sociology, Vol. 14 Nos 1-2, pp. 89-103.

Cohen, E. (1979), "A phenomenology of tourist experiences", Sociology, Vol. 13 No. 2, pp. 179-201.

Cohen, E. (1982), "Marginal paradises: bungalow tourism on the islands of Southern Thailand", Annals of Tourism Research, Vol. 9 No. 2, pp. 189-228.

Cohen, E. (2003), "Backpacking: diversity and change”, Journal of Tourism \& Cultural Change, Vol. 1 No. 2, pp. 95-110.

Cohen, E. (2004), "Backpacking: diversity and change", in Richards, G. and Wilson, J. (Eds), The Global Nomad: Backpacker Travel in Theory and Practice, Channel View Publications, Clevedon, pp. 43-59.

Cohen, E. (2007), "Youth tourists in acre: a disturbance becomes a lifelong preoccupation", in Nash, D. (Ed.), The Study of Tourism: Anthropological and Sociological Beginnings, Elsevier, Amsterdam, pp. 50-9.

Cohen, E. (2018), "Backpacker enclaves research: achievements, critique and alternative approaches", Tourism Recreation Research, Vol. 43 No. 1, pp. 105-16.

Desforges, L. (1998), “'Checking out the planet': global representations/local identities and youth travel”, in Skelton, T. and Valentine, G. (Eds), Cool Places: Geographies of Youth Culture, Routledge, London and New York, NY, pp. 175-92.

Didion, J. (1968/1995), Slouching Towards Bethlehem, Farrar: Straus and Giroux, New York, NY.

Elsrud, T. (2001), "Risk creation in traveling - backpacker adventure narration", Annals of Tourism Research, Vol. 28 No. 3, pp. 597-617.

Falk, G. and Falk, U.A. (2005), Youth Culture and the Generation Gap, Algora Publishing, New York, NY.

Giddens, A. (1991), Modernity and Self-Identity: Self and Society in the Late Modern Age, Polity Press, Cambridge.

Goffman, E. (1961), "Role-distance", in Brissett, D. and Edgley, C. (Eds), Life as Theater: A Dramaturgical Sourcebook, Aldine de Gruyter, NY, pp. 101-11.

González, P.A. and Dans, E.P. (2018), "From intentional community to ecovillage: tracing the rainbow movement in Spain", GeoJournal, pp. 1-19, available at: https://doi.org/10.1007/s10708-018-9917-9

Hail, J. (1979), "Ko Samui: changing. Business”, Times Week, Vol. 1 No. 114, pp. 28-9.

Hampton, M.P. (1998), "Backpacker tourism and economic development", Annals of Tourism Research, Vol. 25 No. 3, pp. 639-60.

Hannam, K. and Diekmann, A. (Eds) (2010), Beyond Backpacker Tourism: Mobilities and Experiences, Channel View Publications, Clevedon.

Hecht, J.-A. and Martin, D. (2006), "Backpacking and hostel-picking: an analysis from Canada”, International Journal of Contemporary Hospitality Management, Vol. 18 No. 1, pp. 66-77. 
Hottola, P. (2008), "Farewell countercultural wanderer? Dress and styles in South Asian backpacking", Tourism Culture \& Communication, Vol. 8 No. 1, pp. 45-52.

Hughes, K., Downing, J. and Bellis, M.A. (2009), "The sexual behaviour of British backpackers in Australia", Sexually Transmitted Infections, Vol. 85No. 6, pp. 477-82.

laquinto, B.L. (2015), “I recycle, I turn out the lights': understanding the everyday sustainability practices of backpackers", Journal of Sustainable Tourism, Vol. 23 No. 4, pp. 577-99.

Ince, A. (2016), "Autonomy, territory, mobility: everyday (geo) politics in voluntary exchange networks", L'Espace Politique. Revue en ligne de géographie politique et de géopolitique, Vol. 28, available at: https://journals.openedition.org/espacepolitique/3779

Ince, A. and Bryant, H. (2018), "Reading hospitality mutually", Environment and Planning D: Society and Space, available at: https://doi.org/10.1177/0263775818774048

Irwin, J. (1977), Scenes, Sage, Beverly Hills, CA.

Iso-Ahola, S.E. (1982), "Toward a social psychological theory of tourism motivation: a rejoinder", Annals of Tourism Research, Vol. 9 No. 2, pp. 256-62.

Jarvis, J. and Peel, V. (2005), "The backpacker boom around the globe", Centre for Global Movements, Monash University, Melbourne, Victoria.

Jenkins, R. (1996), Social Identity, Routledge, London.

Keniston, K. (1968), "Heads and seekers: drugs on campus, counter culture and American society", The American Scholar, Vol. 38 No. 1, pp. 97-112.

Kuhling, C. (2007), "Mobility, marginality and modernity in the new age traveller imaginary", The Irish Review, Nos 36/37, pp. 78-94, available at: www.jstor.org/stable/29736346?

Larsen, J., Axhausen, K.W. and Urry, J. (2006), "Geographies of social networks: meetings, travel and communications", Mobilities, Vol. 1 No. 2, pp. 261-83.

Larsen, S., Øgaard, T. and Brun, W. (2011), "Backpackers and mainstreamers: realities and myths", Annals of Tourism Research, Vol. 38 No. 2, pp. 690-707.

Leary, T. (1983), Flashbacks: An Autobiography, J.P. Tarcher, Los Angeles, CA.

Lewis, R.J. (1972), Outlaws of America, the Underground Press and its Context, Heinrich Hanau, London.

Löfgren, O. (2002), On Holiday: A History of Vacationing (No. 6), University of California Press, Berkeley, CA.

Loker-Murphy, L. (1997), "Backpackers in Australia: a motivation-based segmentation study", Journal of Travel \& Tourism Marketing, Vol. 5 No. 4, pp. 23-45.

Loker-Murphy, L. and Pearce, P. (1995), "Young budget travelers: backpackers in Australia", Annals of Tourism Research, Vol. 22 No. 4, pp. 819-43.

Luo, X., Huang, S. and Brown, G. (2015), "Backpacking in China: a netnographic analysis of donkey friends travel behaviour", Journal of China Tourism Research, Vol. 11 No. 1, pp. 67-84.

McKay, G. (1996), Senseless Acts of Beauty: Cultures of Resistance Since the Sixties, Verso, London.

Mannermaa, M. (1991), "In search of an evolutionary paradigm for futures research", Futures, Vol. 23 No. 4, pp. 349-72.

Maoz, D. (2007), "Backpackers' motivations: the role of culture and nationality”, Annals of Tourism Research, Vol. 34 No. 1, pp. 122-40.

Marwick, A. (1999), The Sixties: Cultural Revolution in Britain, France, Italy, and the United States, c. 1958-c.1974, Oxford University Press, Oxford.

Michener, J.A. (1971), "The drifters, Secker and Warburg", London.

Miles, M. (2008), Urban Utopias: the Built and Social Architectures of Alternative Settlements, Routledge, London.

Mills, R. (1973), "Young outsiders: a study of alternative communities", report of the Institute of Community Studies, Routledge and Kegan Paul, London.

Molz, J. and Paris, C.M. (2015), "The social affordances of flashpacking: exploring the mobility nexus of travel and communication", Mobilities, Vol. 10 No. 2, pp. 173-92. 
Murphy, L. (2001), “Exploring social interactions of backpackers”, Annals of Tourism Research, Vol. 28 No. 1, pp. 50-67.

Neville, R. (1970), Play Power, Jonathan Cape, London.

Niman, M.I. (1997), People of the Rainbow: A Nomadic Utopia, University of Tennessee Press, Knoxville, TN.

Noy, C. (2004), "This trip really changed me: backpackers' narratives of self-change", Annals of Tourism Research, Vol. 31 No. 1, pp. 78-102.

O'Regan, M. (2016), "A backpacker habitus: the body and dress, embodiment and the self", Annals of Leisure Research, Vol. 19 No. 3, pp. 329-46.

O’Reilly, C. (2005), "Tourist or traveller? Narrating backpacker identity”, in Jaworski, A. and Pritchard, A. (Eds), Discourse, Communication and Tourism, Channel View Publications, Clevedon, pp. 150-69.

O'Reilly, C. (2006), "From drifter to gap year tourist: mainstreaming backpacker travel", Annals of Tourism Research, Vol. 33 No. 4, pp. 998-1017.

Page, S.J., Yeoman, I., Connell, J. and Greenwood, C. (2010), "Scenario planning as a tool to understand uncertainty in tourism: the example of transport and tourism in Scotland in 2025", Current Issues in Tourism, Vol. 13 No. 2, pp. 99-137.

Paris, C.M. (2012), "Flashpackers: an emerging sub-culture?", Annals of Tourism Research, Vol. 39 No. 2, pp. 1094-115.

Pearce, P.L. (1990), The Backpacker Phenomenon: Preliminary Answers to Basic Questions, Department of Tourism, James Cook University, Townsville.

Pearce, P.L. and Foster, F. (2007), "A 'university of travel': backpacker learning”, Tourism Management, Vol. 28 No. 5, pp. 1285-98.

Pendergast, T. and Pendergast, S. (Eds) (2000), St James Encyclopedia of Popular Culture, Gale Group, Farmington Hills, MI.

Richards, G. (2015), "The new global nomads: youth travel in a globalizing world", Tourism Recreation Research, Vol. 40 No. 3, pp. 340-52.

Riley, P.J. (1988), "Road culture of international long-term budget travelers", Annals of Tourism Research, Vol. 15 No. 3, pp. 313-28.

Roszak, T. (1969), The Making of a Counter Culture: Reflections on the Technocratic Society and Its Youthful Opposition, Doubleday, New York, NY.

Ryan, C. and Mohsin, A. (2001), "Backpackers attitudes to the 'outback' ", Journal of Travel and Tourism Marketing, Vol. 10 No. 1, pp. 69-92.

Saidi, M. (2018), "Begpackers seen by a third-worldist", Medium, available at: https://medium.com/efyia/ begpackers-seen-by-a-third-worldist-585d408db401 (accessed 1 September 2018).

Saldanha, A. (2002), "Music tourism and factions of bodies in Goa”, Tourist Studies, Vol. 2 No. 1, pp. 43-62.

Scheyvens, R. (2002), "Backpacker tourism and third world development", Annals of Tourism Research, Vol. 29 No. 1, pp. 144-64.

Schoemaker, P.J. (2004), "Forecasting and scenario planning: the challenges of uncertainty and complexity", in Koehler, D.J. and Harvey, N. (Eds), Blackwell Handbook of Judgment and Decision Making, Blackwell, Oxford, pp. 274-96.

Shaffer, T.S. (2004), "Performing backpacking: constructing 'authenticity' every step of the way", Annals of Tourism Research, Vol. 24 No. 2, pp. 139-60.

Slaughter, L. (2004), "Profiling the international backpacker market in Australia", in Richards, G. and Wilson, J. (Eds), The Global Nomad: Backpacker Travel in Theory and Practice, Channel View, Clevedon, pp. 168-79.

Smith, V.L. (1992), "Boracay, Philippines: a case study in 'alternative' tourism", in Smith, V.L. and Eadington, W. (Eds), Tourism Alternatives: Potentials and Problems in the Development of Tourism, University of Pennsylvania Press, Philadelphia, PA, pp. 135-57.

Sørensen, A. (2003), "Backpacker ethnography", Annals of Tourism Research, Vol. 30 No. 4, pp. 847-67. 
St John, G. (2001), "Alternative cultural heterotopia and the liminoid body: beyond turner at confest", The Australian Journal of Anthropology, Vol. 12 No. 1, pp. 47-66.

Stephens, J. (1998), Anti-Disciplinary Protest: Sixties Radicalism and Postmodernism, Cambridge University, Cambridge.

Teas, J. (1988/1974), “'I'm studying.monkeys. What do you do?' Youth and travellers in Nepal”, in Inhorn, M.C. (Ed.), Anthropological Research on Contemporary Tourism: Student Papers from Berkeley, Vols 67/68, Kroeber Anthropological Society Papers, University of California, Berkeley, CA, pp. 35-41.

Thyne, M., Davies, S. and Nash, R. (2004), "A segmentation analysis of the backpacker market in Scotland: a case study of the Scottish youth hostel association", Journal of Quality Assurance in Hospitality and Tourism, Vol. 5 Nos 3-4, pp. 95-119.

Tomory, D. (1996), A Season in Heaven: True Tales from the Road to Kathmandu, Lonely Planet Publications, Hawthorn.

Tucker, H. (2003), Living with Tourism: Negotiating Identities in a Turkish Village, Routledge, London.

Turner, F. (2006), From Counterculture to Cyberculture: Stewart Brand and the Whole Earth and the Rise of Digital Utopianism, Chicago University Press, Chicago, IL.

Uriely, N. (2005), "The tourist experience: conceptual developments", Annals of Tourism Research, Vol. 32 No. 1, pp. 199-216.

Uriely, N., Yonay, Y. and Simchai, D. (2002), "Backpacking experiences: a type and form analysis", Annals of Tourism Research, Vol. 29 No. 2, pp. 519-37.

Vogt, J. (1976), "Wandering: youth and travel behaviour", Annals of Tourism Research, Vol. 4 No. 1, pp. 25-40.

Wallace, B. (1991), "Backpack travellers using commercial backpacker accommodation in Queensland", unpublished masters thesis, Victoria University of Technology, Melbourne, Victoria.

Westerhausen, K. (2002), Beyond the Beach: An Ethnography of Modern Travellers in Asia, White Lotus, Bangkok.

Wheeler, T. and Wheeler, M. (2007), Unlikely Destinations: The Lonely Planet Story, Periplus, Singapore.

Wolfe, T. (1968/1999), Electric Kool-Aid Acid Test, Bantam Books, New York, NY.

Yablonsky, L. (1968), The Hippie Trip, Pegasus, New York, NY.

Yeoman, I. (2008), Tomorrow's Tourist: Scenarios \& Trends, Routledge, London.

\section{Further reading}

Cohen, S.A. (2013), "A portrait of Erik Cohen”, Anatolia, Vol. 24 No. 1, pp. 104-11.

O'Regan, M. (2015), "Methodological bricolage: a journey on the road less traveled in tourism studies", Tourism Analysis, Vol. 20 No. 5, pp. 457-67.

Ray, R.B. (1985), A Certain Tendency of the Hollywood Cinema, 1930-1980, Princeton University Press, Princeton, NJ.

Salazar, N.B. (2010), Envisioning Eden: Mobilizing Imaginaries in Tourism and Beyond, Berghahn Books, Oxford.

\section{About the author}

Michael O' Regan, PhD, worked alongside the National Tourism Development Authority of Ireland before joining Gulliver, and later, Wicklow County Tourism. He has a PhD from the School of Sport and Service Management at the University of Brighton, UK (2010). His research interests are slow, alternative, historic, future and cultural mobilities. Michael O' Regan can be contacted at: moregan@bournemouth.ac.uk

For instructions on how to order reprints of this article, please visit our website:

www.emeraldgrouppublishing.com/licensing/reprints.htm

Or contact us for further details: permissions@emeraldinsight.com 